\title{
MODERN TRENDS OF DEVELOPMENT OF ELECTRONIC TRADE IN THE CONDITIONS OF DIGITAL ECONOMY
}

\author{
Nataliya Tovma $^{1 *}$, Kairzhan Kazbekova. ${ }^{1}$, Kyz-Zhibek Abisheva ${ }^{1}$, Aigerim Nurgaliyeva ${ }^{l}$ \\ ${ }^{1}$ Al-Farabi Kazakh National University, al-Farabi Ave. 71, 050040 Almaty, Republic of Kazakhstan
}

\begin{abstract}
E-commerce is rapidly gaining popularity and is a dynamically developing industry in the global economy. With the help of information technologies, Internet companies are open to opportunities to develop new markets, providing the Internet consumer with great potential for product research. For the further effective development of commercial activity, an important condition is fulfilling the need to assess the main trends and changes in the development of electronic commerce.The purpose of the study is to analyze the development and current state of electronic commerce in the world, as well as develop methods and recommendations for participants in foreign economic activity doing business through the Internet in the interests of expanding companies and increasing the efficiency of their activities. Results. A study of the basic principles of electronic commerce and the factors affecting it. E-commerce systems are presented that enable buyers not only to interact with the seller, but also to receive the most complete information about the goods sold and the services provided. Using the results of the analysis, the state and main trends in the development of electronic commerce are determined. A system of indicators has been supplemented to assess the level of development of international electronic commerce.
\end{abstract}

\section{Introduction.}

In modern economic conditions, there is a dynamic development of a promising segment of the domestic economy - electronic commerce. The spread of broadband Internet access provides an opportunity to open up new markets. E-commerce systems enable customers not only to interact with the seller, but also to receive information on the goods sold and the

\footnotetext{
* Corresponding author: Tovma.Natali@kaznu.kz
} 
services provided. Sellers are able to quickly respond to changing consumer behavior, demand dynamics, as well as reduce the cost of renting premises and company personnel [1].

E-commerce turnover and the number of online stores are constantly growing. This is due to the fact that the number of users, social media, as well as the development of Internet payments is increasing [2].

Nowadays, like never before, e-commerce is very popular in the world. The turnover of funds in the field of direct sales, that is, sales "from seller to consumer" amounted to more than 1.3 trillion dollars, between companies - 15 trillion in dollars. According to the results of analysts and experts in the field of electronic commerce in 2018, in countries that are economically transitional and developing countries, e-commerce will occupy more than $40 \%$ of total trade indicators, while in developed countries this indicator is somewhat will decrease from 70 to $60 \%$ [7].

Currently, in the countries of the European Union, electronic commerce has become an integral part of the functioning of enterprises [8]. (Nadtochy Yu.I., 2010, Sudakova N.A., 2008). About one in six European companies employing more than ten employees sold their goods and services online last year. Almost all of them (97\%) engage in online sales within their own country, $44 \%$ trade with customers from various countries of the European Union, and $28 \%$ trade with countries outside the EU [9].

The term "electronic commerce" is actively used in the literature along with such concepts as "Internet commerce", "electronic commerce" and "digital commerce". The active development of electronic commerce in various countries is associated with the presence of a favorable socio-economic climate and the formation of a complex of factors that create a positive background and basic basis. The intensive growth of mass communication media has also determined changes in the sphere of entrepreneurial activity and doing business [10].

The electronic commerce system between companies can be implemented on the basis of cashless payments, between enterprises and individuals - consumers of products. In accordance with this division, there are 2 types of electronic commerce based on 2 types of interaction: "business-to-business B2B" and "business-client" (Business-to Consumer, B2C) [11].

The basic element of electronic commerce is now electronic trading platforms and online stores. E-commerce includes five main areas of activity:

- advertising (targeted, non-targeted, non-individualized advertising);

- Presentation of goods and services (electronic catalogs tied to an electronic platform or online store);

- Conducting basic operations for the selection of goods, filling in an electronic basket, working with an electronic payment system, tracking the implementation of an order;

- After-sales support, warranty service, etc .;

- marketing of relationships (partnerships) [10].

Another area of e-commerce development is the use of crypto currency. The founder of the crypto currency is David Chom. He invented a centralized payment system for confidential payments in the DigiCash system, but in 1998 the company ceased to exist [12]. (Matkovsky I, 2019). The resumption of crypto currency development was due to the advent of the decentralized payment system Bitcoin, which was developed in 2009 by an unknown programmer [13]. Today, crypto currency is one of the types of digital currency. Its emission and accounting are based on various cryptographic methods, its functioning is decentralized in a distributed computer network. Cryptocurrency is a real software product, the rate of which depends on the levels of supply and demand.

The highest concentration of online trading companies is in Ireland (26\%), Sweden (25\%) and Denmark (24\%). At the same time, in Romania (7\%), Bulgaria and Poland (9\%), Italy and Latvia (10\%) - a rather low level of development of companies engaged in electronic commerce [5]. 
According to E-Commerce Foundation research, last year, e-commerce in Denmark was worth 13.5 billion euros after an increase of $15.88 \%$ compared to 2015 . It is currently projected that this industry will be more than 15.5 billion euros at the end of this year. It is also known that $32 \%$ of online shoppers in Denmark bought abroad. The most popular crossborder shopping destination is the United Kingdom, followed by Germany, the USA, China and Sweden. The most important reason to buy on foreign e-commerce sites is lower prices [14].

Recently, experts have noted the growth of e-commerce in the UK. It amounted to just over $19 \%$ of this country's annual income. If we take the pan-European indicators, then ecommerce

The UK will account for approximately $30 \%$ of the European total revenue. This will include not only retail, but also wholesale, sales of exclusive goods. If these indicators are not taken into account, then e-commerce will be approximately $26 \%$ of sales, in our country this figure is much lower, and ranges from 2 to $3 \%$. According to the results of various expert groups and analysts, over the course of 5 years this indicator will increase to $40 \%$ [15].

In the future, electronic commerce will be built on multi-format and multi-industry electronic platforms, and the combined usefulness of products will be created by the efforts of all participants. As basic services, individualized information on supply and demand, the choice of a product or service, an online contract, an online transaction, electronic logistics, and analytical forecasting will be offered.

\section{Literature review}

An analysis of current trends in the development of electronic commerce is given in the works: O. Vlasova [1], Kazmina I.V. [11], Pimenova G.G. [2], Varlamova Yu.A. [9].

The development of electronic commerce in Kazakhstan was carried out by such researchers as: Ziyadin S.T. [16], Mutanov G.M. [17], Sash N. [18], Toluyev J. [19], Schedenov U.K., Askarov F. [20], Onaltaev D., Kazhmuratova A., Akhmetkalieva S., Malikova R.M [21].

In the works of foreign scientists researching the development of international economic relations, the problem of international electronic commerce has also been reflected. Among the works that have made a significant contribution to its study and development, the fundamental works of scientists should be distinguished: Sudakova N.A. [5], Maksimenko A.A. [6], Aksenova A.A. [7], Nadtochy Yu.I. [8], Sidorova G.M. [22], Granin Yu.D. [14], Korolkov V.E. [fifteen].

The work also uses the works of well-known foreign researchers involved in the effectiveness of electronic commerce, such as D. Luzin. [23], Matkovsky I. [24] a number of others.

At the same time, in foreign and domestic works, the research topic is not comprehensively developed, there is no detailed consideration of e-commerce trends, little attention is paid to problems that impede the expansion of international e-commerce, questions on ensuring international delivery of goods in the framework of the establishment of electronic business are not fully covered.

\section{Data and methodology}


The development of e-commerce was made possible thanks to a large-scale system program for the development of the economy of a new technological generation, the so-called digital economy.

The theoretical basis of the study was the work of domestic and foreign authors describing the influence of the information sphere and the spread of the Internet space, the digital economy on Internet trade, which allowed us to consider the development of its main directions.

When writing the article, a wide range of analytical methods was used - statistical analysis, forecasting, comparison, theoretical generalization, statistical data processing, data analysis in dynamics.

Studying and analyzing the transformation of marketing in the context of the development of the digital economy implies the development and application of a system of indicators and indicators that really reflect the actual state and development directions of the EAEU Internet space, which are reflected in the economic literature. Indicators differ in the number of indicators included, target orientation, research coverage, which allows to identify the position of the region relative to another, that is, to conduct a comparative analysis of them. The article analyzed the rating of the countries of the world in terms of the development of information and communication technologies, data from world Internet statistics, and reporting data from a report on the information economy.

Currently, there are several international ratings that directly or indirectly characterize the levels of development of information and communication technologies and the maturity of e-government tools in different countries of the world.

The most authoritative are the ratings of the United Nations (UN), the International Telecommunication Union (ITU), the World Economic Forum (WEF) and the World Bank (WB).

In the article, the described indicator was used to reflect the level of development of Internet technologies in the EAEU countries in comparison with world standards.

The dialectical research method was the general methodological basis of cognition using a systematic approach to the processes of transnationalization and economic development. Correlation and regression analysis of official statistical materials of federal executive bodies and international statistical databases. The information and legislative base of the work was composed of laws, UN, EU model laws, statistical materials (Rosstat, Internet World Stats, Eurostat, World Bank, UNCTAD, data from the Eurasian Economic Commission), information and analytical studies of Data Insight agencies, and the Association of Internet Companies Trade (AKIT) ", Association of Kazakhstan Internet Business (AKIB), “J'son and Partners management consultancy ", Statista.com ”[23]. During the study, we analyzed both official statistics and industry surveys, data from business associations and companies .. At the same time, we conducted a series of in-depth interviews with representatives of the e-commerce sector.

\section{Results and discussion}

According to industry experts, a significant increase can come from electronic trading in intangible goods (about $20-25 \%$ per year), which is practically not taken into account by market experts in the total volume of online sales. This can be explained by the fact that so far there has not been a single international practice of recording and evaluating the indicators of the emerging online trading market [25].

Figure 1 shows the position of states in the market for online trade in services and goods. According to Remarkety, in 2017, China became the largest online trading market in the world. The main growth factor is the country's population [25]. 


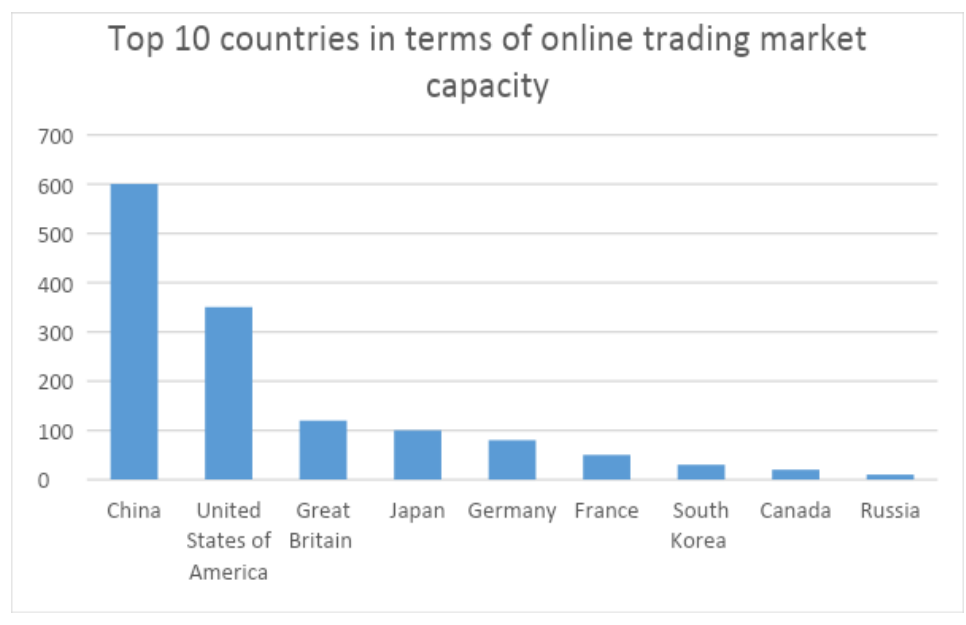

Fig. 1. TOP 10 countries - leaders in terms of capacity of online trading markets Source - according to the literature [25].

The high growth rate of the PRC economy over the past few years, as well as expert forecasts regarding their preservation and further growth, testify to the preservation and increase of China's leading position in global e-commerce. Some countries already include protectionist barriers to the relatively high-quality and low-cost market for services and goods offered by Chinese online stores. According to expert forecasts, a significant growth of the global online trading market should be expected over the next few years (Fig. 2). EMarketer experts predict that by 2019 , sales will grow to $\$ 3.5$ trillion [5]. At the same time, the share of online trading in world retail will increase to $12 \%$, compared with 8-9\% in 2015 [6].

The main factor in the growth of the online trading sector is a steady influx of new Internet users, mainly mobile Internet users (tablets, smartphones) [25]. It is also necessary to take into account the general global trend of digitalization of society in order to minimize costs on any operations and transactions, if they can be transferred to the global network. EMarketer experts predict that in the near future there will be a significant increase in the number of purchases, including due to increased price competition between market players. This is due to the fact that online consumers have the opportunity to compare prices of different sellers (including in the marketplace format), which acts as a driver for holding regular and frequent promotions by both traditional and electronic retailers [25]. According to experts, China will continue to lead the global online trading market (26\% per year) [25]. Mainly due to export retail sales. Rather high growth rates are expected in other emerging economies: in India (24\%), in Indonesia and South Korea (more than 20\%). The key drivers of growth in these regions are the demographic situation (high population) and mobile Internet penetration. The growth of markets of developed countries (Japan, Germany, Great Britain, the United States) will be significantly affected by mobile sales (Table 1). 


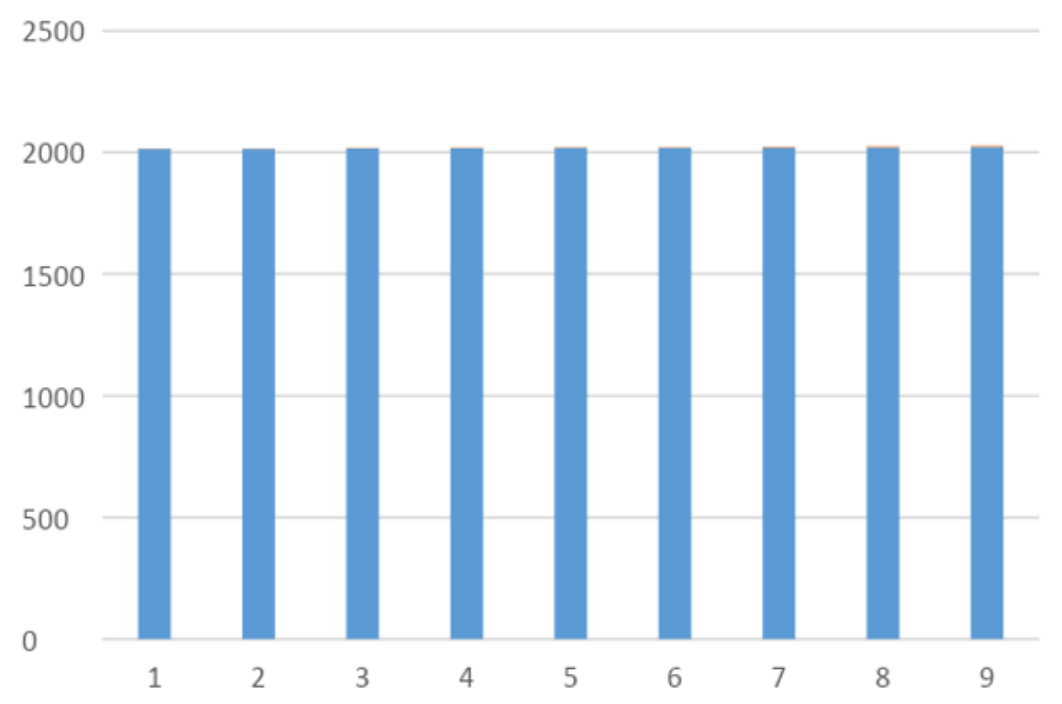

Figure 2 - Growth of the global e-commerce market Source - according to the literature [25].

\begin{tabular}{|l|l|l|l|l|l|l|l|l|}
\hline $\begin{array}{l}\text { The } \\
\text { country }\end{array}$ & \multicolumn{2}{|l|}{$\begin{array}{l}\text { Online sales, } \\
\text { billion US dollars }\end{array}$} & \multicolumn{2}{l|}{$\begin{array}{l}\text { Online Trading } \\
\text { Share } \\
\text { whether in total } \\
\text { retail,\% }\end{array}$} & \multicolumn{2}{l|}{$\begin{array}{l}\text { Online shopping } \\
\text { share- } \\
\text { tele, \% of the } \\
\text { population } \\
\text { countries }\end{array}$} & $\begin{array}{l}\text { The proportion } \\
\text { of online } \\
\text { shoppers, \% } \\
\text { of the world's } \\
\text { population }\end{array}$ \\
\hline & 2015 & 2019 & 2015 & 2019 & 2015 & 2019 & 2015 & 2019 \\
\hline China & 674 & 1974 & 17 & 35 & 38 & 53 & 29 & 30 \\
\hline USA & 342 & 536 & 7,3 & 10,3 & 66 & 72 & 10 & 13 \\
\hline $\begin{array}{l}\text { Great } \\
\text { Britain }\end{array}$ & 100 & 144 & 16 & 19,4 & 76 & 79,8 & & \\
\hline Japan & 91 & 135 & & & 69,5 & 74 & 5 & 6 \\
\hline Germany & 63 & 89 & & & 67,7 & 71 & & \\
\hline & & & & & & & & \\
\hline
\end{tabular}

Table 1 - Development of the online trading market in the leading countries

The development and expansion of online trading leads to more rapid globalization and faster information exchange. At the same time, the development of online commerce is one of the main global trends in economic development. All e-commerce is based on principles. Modern principles of electronic business can be formulated as follows (table 2):

\begin{tabular}{|l|l|l|}
\hline № & \multicolumn{1}{|c|}{ Principle } & \multicolumn{1}{c|}{ Justification } \\
\hline 1 & Justification & Speed of processing and exchange of information. \\
\hline 2 & Business value. & $\begin{array}{l}\text { Currently, the value of a business is estimated not only } \\
\text { by material resources, but also not material. }\end{array}$ \\
\hline
\end{tabular}




\begin{tabular}{|l|l|l|}
\hline 3 & $\begin{array}{l}\text { The concept of distances between } \\
\text { opponents is leveled. }\end{array}$ & $\begin{array}{l}\text { Anyone can act as a buyer. Huge opportunities open up } \\
\text { for entrepreneurs, since any person, regardless of } \\
\text { location, can act as a buyer. }\end{array}$ \\
\hline 4 & $\begin{array}{l}\text { The importance of intellectual } \\
\text { potential. }\end{array}$ & $\begin{array}{l}\text { Creative ideas, revealing latent demand, quick response } \\
\text { to new needs bring significant income. }\end{array}$ \\
\hline 5 & $\begin{array}{l}\text { Instant adaptation of the company } \\
\text { to market requirements. }\end{array}$ & $\begin{array}{l}\text { The presence of direct and feedback with consumers, the } \\
\text { interactivity of the enterprise, becomes an important } \\
\text { success factor. }\end{array}$ \\
\hline 6 & $\begin{array}{l}\text { Simplicity and high speed of } \\
\text { information transfer. }\end{array}$ & $\begin{array}{l}\text { Through the Internet network information about the } \\
\text { characteristics, properties of the new product, } \\
\text { advertising materials are distributed instantly. }\end{array}$ \\
\hline 7 & $\begin{array}{l}\text { Attraction of information } \\
\text { intermediaries. }\end{array}$ & $\begin{array}{l}\text { The goal of attracting information intermediaries is to } \\
\text { process a huge stream of data that are important for a } \\
\text { particular entrepreneur. }\end{array}$ \\
\hline 8 & $\begin{array}{l}\text { Using modern information } \\
\text { processing tools. }\end{array}$ & $\begin{array}{l}\text { Using modern tools, you can make a comparative } \\
\text { analysis of the prices of goods, get additional } \\
\text { information and choose the most attracted brand. }\end{array}$ \\
\hline 9 & Personal approach to each client & $\begin{array}{l}\text { With the help of modern Internet marketing tools, a } \\
\text { personal approach to each client should be observed. }\end{array}$ \\
\hline 10 & $\begin{array}{l}\text { Time saving } \\
\text { N significant reduction in the time between the desire to } \\
\text { buy and the actual purchase. It creates additional } \\
\text { amenities for consumers. }\end{array}$ \\
\hline Note - developed by the authors & \\
\hline
\end{tabular}

Table 2 - Ecommerce Principles

\begin{tabular}{|l|l|l|l|l|}
\hline № & \multicolumn{3}{|c|}{ The main factors of development and organization of electronic commerce } \\
\hline 1 & Market & Information & Managerial & Legal \\
\hline 2 & Market fragmentation & $\begin{array}{l}\text { The presence } \\
\text { of the } \\
\text { economic } \\
\text { component }\end{array}$ & $\begin{array}{l}\text { Management } \\
\text { Interest }\end{array}$ & Legality of Laws \\
Legal literacy \\
\hline 3 & $\begin{array}{l}\text { The presence of } \\
\text { competition }\end{array}$ & $\begin{array}{l}\text { Business } \\
\text { process } \\
\text { automation }\end{array}$ & $\begin{array}{l}\text { Willingness } \\
\text { to cooperate }\end{array}$ & $\begin{array}{l}\text { Guarantees of judicial } \\
\text { protection }\end{array}$ \\
\hline 4 & Unique products & $\begin{array}{l}\text { Wireless } \\
\text { technology }\end{array}$ & $\begin{array}{l}\text { Level of } \\
\text { qualification } \\
\text { of employees }\end{array}$ & \\
\hline
\end{tabular}

Various factors influence the development of e-commerce (table 3).

Table 3 - The main factors of development and organization of electronic commerce

Ecommerce has great benefits. Table 4 lists the main advantages of electronic commerce and the resulting effect.

\begin{tabular}{|l|l|l|}
\hline № & Ecommerce Benefits & Effect obtained \\
\hline 1 & $\begin{array}{l}\text { Save time on delivering product information to } \\
\text { consumers }\end{array}$ & Time saving \\
\hline 2 & Round-the-clock access without time zones & Lower time and cost \\
\hline
\end{tabular}




\begin{tabular}{|c|c|c|}
\hline 3 & $\begin{array}{lll}\text { Direct manufacturer-buyer } & \text { relationship, } \\
\text { reduction of intermediaries } & \\
\end{array}$ & Financial cost reduction \\
\hline 4 & Providing real-time trading & $\begin{array}{l}\text { Reducing time costs, increasing the } \\
\text { number of orders. }\end{array}$ \\
\hline 5 & Competitive growth & The increase in sales of goods \\
\hline 6 & Formation of the flow of potential customers & Market expansion \\
\hline 7 & Expanding Product Information Types & $\begin{array}{l}\text { Improving the quality and soundness of } \\
\text { advertising }\end{array}$ \\
\hline 8 & Customer satisfaction & $\begin{array}{l}\text { Increased advertising, increasing the } \\
\text { number of customers. }\end{array}$ \\
\hline 9 & $\begin{array}{l}\text { Significant reduction in staff costs and rental } \\
\text { of premises }\end{array}$ & Financial cost reduction \\
\hline 10 & Expanding the variety of forms of payment & $\begin{array}{l}\text { Simplification of calculations and } \\
\text { interaction with suppliers }\end{array}$ \\
\hline 11 & Increase in cash due to electronic payments & The growth of the economy \\
\hline 12 & Increase in cash due to electronic payments & $\begin{array}{l}\text { Increased investment in the } \\
\text { manufacturing sector }\end{array}$ \\
\hline
\end{tabular}

\section{Table 4- Key Ecommerce Benefits}

These benefits are largely interrelated. Raising the competitiveness of the industry through e-commerce is due to personalization of the service, an increase in the volume of investments in the manufacturing sector, a decrease in temporary financial costs, and an increase in costs. Along with the advantage, there are problems of the development of electronic commerce. Table 5 shows the main problems in the development of electronic business. On the one hand, the elimination of these problems in the organization of electronic commerce will provide an opportunity to build a global business on the Internet.

\begin{tabular}{|l|l|l|}
\hline № & Ecommerce Benefits & Effect obtained \\
\hline 1 & The number of Internet users is not enough & $\begin{array}{l}\text { Creation of conditions for advertising } \\
\text { and new Internet networks }\end{array}$ \\
\hline 2 & Lack of funds to finance Internet projects & $\begin{array}{l}\text { The adoption of regional programs for } \\
\text { the development of Internet projects }\end{array}$ \\
\hline 3 & $\begin{array}{l}\text { The need to expand the system of payments } \\
\text { with credit cards and payment systems }\end{array}$ & $\begin{array}{l}\text { The adoption of the state program for the } \\
\text { creation of new and development of } \\
\text { existing Internet projects }\end{array}$ \\
\hline 4 & $\begin{array}{l}\text { The need to develop communications system } \\
\text { infrastructure using promising channels }\end{array}$ & $\begin{array}{l}\text { Creating the conditions for completing } \\
\text { the construction of a wireless network }\end{array}$ \\
\hline 5 & $\begin{array}{l}\text { The need to expand the number of financial } \\
\text { institutions providing online services }\end{array}$ & $\begin{array}{l}\text { Creation of additional banking nodes for } \\
\text { goods and banking operations }\end{array}$ \\
\hline 6 & $\begin{array}{l}\text { Recognition of the legality of new forward- } \\
\text { looking payments }\end{array}$ & $\begin{array}{l}\text { Improving the efficiency of legislative } \\
\text { bodies }\end{array}$ \\
\hline 7 & Securing Internet Payments & $\begin{array}{l}\text { Strict leadership of information security } \\
\text { concept }\end{array}$ \\
\hline 8 & The need for legislation & $\begin{array}{l}\text { Development and approval of legislation } \\
\text { on electronic commerce }\end{array}$ \\
\hline 9 & Lack of training for IT managers & Further training for employees \\
\hline
\end{tabular}

Table 5 - Problems of the development of electronic commerce and ways to solve problems 
Based on official statistics, the authors found a relationship between indicators of electronic commerce development and significant macroeconomic indicators (table 6).

\begin{tabular}{|l|l|c|}
\hline \multicolumn{1}{|c|}{ Dependence } & Regression level & Coefficient of determination \\
\hline $\begin{array}{l}\text { 1. The dependence of GDP per } \\
\text { capita on the Index } \\
\text { e-commerce development in } \\
\text { the world }\end{array}$ & $\begin{array}{l}0,0588 \mathrm{x} \\
\mathrm{y}=380,82 \mathrm{e}\end{array}$ & 0,851 \\
\hline $\begin{array}{l}\text { 2. The dependence of GDP per capita in countries of the world on sub-indices of the E-commerce } \\
\text { Development Index: }\end{array}$ & \\
\hline $\begin{array}{l}\text { 2.1 Proportion of individuals } \\
\text { using the global Internet }\end{array}$ & $\begin{array}{l}1,2445 \\
\mathrm{y}=72,842 \mathrm{x}\end{array}$ \\
\hline $\begin{array}{l}\text { 2.2 The proportion of persons } \\
\text { using bank cards in } \\
\text { quality of payment in } \\
\text { electronic commerce }\end{array}$ & $\mathrm{y}=799,06 \mathrm{x}-297,37$ & 0,734 \\
\hline 2.3 Internet Server Security & $\mathrm{y}=0,0079 \mathrm{x} 3,3402$ & 0,705 \\
\hline \begin{tabular}{l} 
2.4 Postal reliability (delivery) \\
\multicolumn{2}{|l|}{}
\end{tabular} & $\begin{array}{l}1,5233 \\
\mathrm{y}=15,569 \mathrm{x}\end{array}$ & 0,511 \\
\hline $\begin{array}{l}\text { 3. The dependence of the BBB } \\
\text { per capita on the level } \\
\text { countries of the world }\end{array}$ & $0,043 \mathrm{x}$ & 0,729 \\
\hline $\begin{array}{l}\text { 4. Dependence of the Quality } \\
\text { of Life Index on the proportion } \\
\text { Internet shoppers in the total } \\
\text { population } \\
\text { countries of the world }\end{array}$ & $\mathrm{y}=678,47 \mathrm{e}$ & 0,820 \\
\hline $\begin{array}{l}\text { 5. The dependence of labor } \\
\text { productivity in trade on } \\
\text { Worldwide E-Commerce } \\
\text { Development Index }\end{array}$ & $\mathrm{y}=0,0309 \mathrm{x}+5,6209$ & \\
\hline Note - developed by the authors & $\mathrm{y}=0,0009 \mathrm{x}$ & \\
\hline
\end{tabular}

Table 6 - Analytical relationships between indicators of the development of electronic commerce and macroeconomic indicators

Based on the constructed dependencies, e-commerce development indicators were predicted, the results of which showed a positive trend. In particular, this refers to the IRET, which by 2020 will amount to $53.6 \%$, that is, the EAEU countries will reach $67.7 \%$ of the level of electronic commerce development in the EU. Based on the gradation of the analyzed indicator (from 50 to 74 inclusive), the EAEU countries have reached the average level of electronic 


\section{Conclusion}

The first experience of electronic commerce led to the conclusion:

1. The electronic business takes root where services are provided to enterprises operating in an adequate infrastructure environment.

2. Without automation of technological processes of enterprise resource management, including procurement management, production and marketing. A promising task is the formation of electronic commerce, which will provide:

1. IT - accumulation and processing of open data about business and people for decision making

2. The penetration of electronic communications in various industries and sectors of the economy, including manufacturing and the labor market.

3. Remote control and management of business operations.

1. Logistics optimization

2. Accurate forecasting of demand and individual production of goods and services based on the results of a significant amount of data.

3. Profit exclusively through innovation

4. Integration of big data at the national and international levels.

The rapid development of multimedia communications, a high degree of adaptation of the population to modern means of communication, the formation of a system of legal, technological support and economic support for electronic commerce contributes to its continuous improvement. The transformation of economic relations is going towards the development of the digital economy in general and electronic commerce in particular.

\section{Thanks.}

The article was written as part of project No. AP05135078 "Formation and development of the digital economy in the Republic of Kazakhstan: theory and practical implementation measures".

\section{References}

1. O. V. Vlasova, Journal "Economics and Organization Management". 85-88.

2. G. G. Pimenov Economics and Entrepreneurship. 1 (78) 433-436 2017

3. Yu. A Varlamova., N. I Larionova. Household Savings and Social Capital: A Cluster Approach // (Moscow University Bulletin. Series 6 Economics. 2013) 5 (64-73)

4. E. N. Sheremeteva, T. E. Stepanova, Russian Entrepreneurship, 3 (69-72) 2002

5. N. A Sudakova. American Individual Enterprises: Current Status and Organization // USA and Canada: Economics, Politics, culture. 5 (93-113) 2008.

6. A. A. Maksimenko, L. N. Shmigirilova, Russian and foreign technical and technological centers: analysis of activity, focus, prospects, impact on the global technosphere // Modern problems of science and education. 6 (1573) 2014. 
7. Aksenova A.A. Observance by individuals of currency and tax laws in the presence of accounts in foreign banks // In the collection: Open innovation Collection of articles of the International Scientific and Practical Conference, 2 (16-18) 2017

8. Yu. I. Nadtochy, The choice of France: "Atlantism" with a "European subtext" // Actual problems of Europe, 3 (35-62) 2010

9. Yu. A. Varlamova, N. I. Larionova, Cluster approach, (M. 2019)

10. T. N. Makarova Current status and drivers of e-commerce development.

11. I. V. Kazmina, Creation and features of the functioning of regional innovation systems. // Territory of science, 6 (57-65) (2017).

12. I. Matkovsky Who invented secure electronic money? [Electronic resource] // Project "People" https://www.peoples.ru/. (2014) URL: https://www.peoples.ru/ technics / programmer / david_chaum / (accessed: 06/28/2019).

13. A. V. Babkin, D. D. Burkaltseva, V. V. Pshenichnikov, A. S. Tyulin, Scientific and Technical Journal of St. Petersburg State Polytechnic University. Economic sciences, 5 (2017)

14. Yu. D. Granin, Globalization: the dialectic of historical forms of implementation // The Century of Globalization, 1 (90-103) (2014)

15. V. E. Korolkov, Investment strategy of developing countries in the global investment space // 1, ( Integral. 2013)

16. S. Ziyadin, A. Borodin, E. Streltsova, S. Suieubayeva, D. Pshembayeva, Polish Journal of management studies, 10 (19-1), (492- 504), 2019,

17. G. Mutanov, S. Ziyadin, A. Shaikh, Graphic model for evaluating the competitiveness and eco-efficiency of eco-innovative projects, Entrepreneurship and Sustainability Issues, 6 (4) 2136-2158 (2019) http://doi.org/10.9770/jesi.2019.6.4(41)

18. S. Ziyadin, N. Shash, T. Levchenko, S. Khudaibergenova, G. Yessenova, Modeling of resultant effects in assessment of innovative activity of the hotel organizations, Entrepreneurship and Sustainability Issues 6 (4) 2180-2193 (2019) http://doi.org/10.9770/jesi.2019.6.4(43)

19. J. Tolujevs, O. Shedenov, \& G. Askarov, Investigation of Road Transport Enterprise Functioning on the Basis of System Dynamics. Transport and Telecommunication Journal, 19 (1), 1-9. (2018).

20. D. Onaltayev, A. Kazhmuratova, S. Akhmetkaliyeva, R. Malikova, A. Yelyubayeva, Application of technological innovations in marketing activities of the enterprise. E3S Web of Conferences.

21. G. M. Sidorova, The role of the European Union in resolving crisis situations in Africa // In the collection: International aspects of conflict situations in Africa Ser. "UN Support. The Force of Law", 34-42 (2009)

22. D. A. Luzin, D. A. Luzin, N. P. Shevelev, A. S. Nikonova, E.V. Kurushina, Management of economic systems (electronic journal of Higher Attestation Commission) - 1 (95) (2017)

23. N. P Sheveleva, D. A. Luzin, Journal "Hypothesis", 2 (28-32) 2018

24. V. K. Shaydullina, E-commerce and its development prospects in the world economy // University Bulletin, 3 (114-1118) 2019. 